\title{
Dismissal of The Governor on Charges of Blasphemy Crime
}

\author{
Moh. Saleh \\ Faculty of Law, Airlangga University \\ Surabaya, Indonesia \\ Saleh.nwa@gmail.com
}

\begin{abstract}
Dismissal of the Governor as the form of responsibility based on use of the authority must be imposed in accordance with the classification of faults. It is based on the principle of geen bevoegdheid zonder verantwoordelijkheid. The Law Number 23 of 2014 enacted in detail the mechanisms of the Governor dismissal based on the classifications of faults. The classifications of faults consist of general faults; specific faults; coupled with not performing the national strategic programs. If the general faults made by the governor, dismissal will be done through submission of proposal to the Regional Representative Council (DPRD). If specific faults made by the governor, the dismissal procedure will be done through temporary dismissal. When not performing the national strategic programs, dismissal will be done through administrative sanction mechanism by President. In the case of Blasphemy Crime that is charged to Basuki Tjahaja Purnama cannot be justified for dismissing Basuki Tjahaja Purnama as the Governor of Jakarta, because indictment charged to Basuki Tjahaja Purnama can be regarded as specific maximum threat, not a specific minimum threat based on Article 83 paragraph (1) The Law Number 23 of 2014.
\end{abstract}

Keywords-Responsibility; Classification of Faults; Blasphemy Crime; Dismissal of The Governor.

\section{INTRODUCTION}

Since the enactment of amendment of the 1945 Constitution of The Republic of Indonesia, it can be said that Indonesia claims as the rule of law as mentioned in article 1 paragraph (3) that "Indonesia is the rule of law". The rule of law cannot be justified only from the existence of existing law and principles of the rule of law in the constitution but also from practical implementation of the government. It is based on the opinions of Bagir Manan1 dan Adnan Buyung Nasution2 which stated that constitutional government not only seen from rule series or constitutional principals within the constitution, but it also need to be seen from daily implementation of the regulations or practical implementation of the government. Same opinion also delivered by Detlev Vagts dan Anne-Marie Burley "Constitutional democracy is not the institutions established by the constitution, but the drive and determination individuals they represent".3

Implementation of the rule of law principal in Indonesia as mentioned above can be seen from dismissal of the Governor on blasphemy crime charge as regulated in the Indonesian Criminal Code article 156a which stated that "someone can be convicted maximum 5 years in prison when he or she is proven on purpose in public conducting or stating: a something which stimulate hostility, abuse or blasphemy toward religions in Indonesia...". Besides, it is also ruled in article 156 of Indonesian Criminal Code that "Individual whoever deliver hostility, hatred or contempt into something or numerous Indonesian groups in public can be convicted maximum 4 years in prison or a fine with maximum amount four thousand and five hundred rupiah".

Dismissal of governor related to blasphemy crime charge has happened in Jakarta Indonesia in which Basuki Tjahaja Purnama as the defendant. This case happened in the 
Archepilago of Seribu on 27 September 2016 in which the defendant stated"...therefore don't trust with what people say, probably in your heart you will say I can not choose him as the governor, well - deceived by Al Maidah 51 something like that....".4 The statement stated by Basuki Tjahaja Purnama made him convicted by East Jakarta Disctrict Court on 01 December 2016 under lawsuit no 1537/Pid.B/2016/PN JKT.UTR, with first indictment Article 156a and the second indictment Article 156 of Indonesian Criminal Code5.

Blasphemy crime charge to Basuki Thahaja Purnama becomes major debate for Indonesian Law expert in which this issue cannot be used as justification to dismiss Basuki from his position as governor of DKI Jakarta. The debate occurs because of numerous interpretation of article 83 paragraph (1) and (2) The Law Number 23 of 2014 concerning Local Government which stated:

(1)Temporary dismissal of governor and vice governor can be conducted without any proposal to regional parliament because of their action in performing criminal acts which can be convicted minimum 5 years in prison, corruption, terrorism, treason, threatening national security, and/or other actions which pottentialy able to threaten the unity of Indonesia.

(2)Governor and/or vice governor will be dismissed temporarily from their position as mentioned above in which it is started from the date of the case is registered in the court.

Numeorus law experts argue that Basuki Tjahaja Purnama shall be dismissed from his position as governor since he is convicted in breaching article 156a of Indonesian Criminal Code and this case was registered in the district court of East Jakarta. Meanwhile, numerous legal experts also argued that Basuki Tjahaja Purnama cannot be dismissed from his position since the punishment is not is not more than 5 years of prison.
The present study aims to elaborate classification and mechanism of DKI Jakarta governor's dismissal concerning the issue of blasphemy criminal charge.

\section{CLASSIFICATION OF FAULTS AND MECHANISM OF GIVERNOR DISMISSAL}

The Law Number 23 of 2014 set numerous forms of faults which can be used as an execuse to dismiss governor. Those forms can be classified into 3 sections which are general, specific and not performing national strategic program.

1. General Faults

General faults are stated in article 78 paragraph (2) letter $b$ to $f$ and letter $h$ The Law Number 23 of 2014 which are:

a. Fail to perform duty within 6 months continuously;

b. Declared breaking oath/promise as governor/vice governor;

c. Not performing duty of governor and vice governor as referred in article 67 letter $\mathrm{b}$ The Law Number 23 of 2014 disobey all provision of the laws;

d. Violating the rule as governor and vice governor as referred in article 67 paragraph (1), except letter c, i, and $\mathrm{j}$ The Law Number 23 of 2014 which are:

e. Make policy to give personal gain for family, elite, certain group of people, or certain political group in which it is opposed to the provisions of laws;

2. Make policy which harm public interest and disrupting group of people or discriminating individual and/or group of people as opposed to the provision of laws; 
3. Abusing authority for private interest and/or detrimental to the area that led;

4. Performing corruption, collution, and nepotism also receive money, goods, and/or services from other party in creating policy;

5. Become advocate or legal counsel for legal case as referred to article 65 paragraph (1) letter e The Law Number 23 of 2014 "as regional representative inside and outside court according to the laws";

6. Abusing authority and breaching oath/promise of his/her reign; and

7. Perform double position as other country state official as referred in the laws.

f. Behaving abominably;

h. Utilizing document and/or fake information to in fulfilling the requirements as the candidate of governor/vice governor based on effidence from the institution who published the authentic;

Besides, general faults also stated in article 85 paragraph (1) The Law Number 23 of 2014 concerning public trust crisis because of criminal offense conjecture related to duty, authority and obligation of governor and vice governor which is stated in article 65 paragraph (1) and (2) The Law Number 9 of 2015 concerning second amendement of The Law Number 23 of 2014 about Local Government (The Law Number 9 of 2015) coupled with article 67 and 69 paragraph (1) The Law Number 23 of 2014. Article 65 paragraph (1) and (2) The Law Number 9 of 2015 which are:

\section{(1)Duties of the Governor:}

a. Lead the implementation of government duties and local authority of regional government based on provisions of Laws and policies that are imposed together with Regional Representative Council;

b. Maintain peace and public order;

c. Drafting, proposing and discussing the draft of regional regulations concerning long-term regional development plan, medium-term regional development plan, work and budgets plan of regional government into Regional Representative Council;

d. Drafting, proposing and presenting the draft of regional regulations concerning regional budget into Regional Representative Council;

e. Acting as regional representative inside and outside the court, coupled with able to assign legal counsel to representing the governor as referred in the laws; dan

f. Deleted.

g. Perdoming other duties as referred to provision of the laws.

(2) In performing duty as referred in paragraph (1), governor holds authority to:

a. Proposing the draft of regional regulations;

b. Stipulate regional regulations that are approved by the Regional Representative Council;

c. Stipulate regulations and policies of the governor;

d. Take certain action in emergency situation which is very required by the region and/or society;

e. Conducting other authorities as referred to the provisions of laws.

Article 67 and 69 paragraph (1) The Law Number 23 of 2014 concerning obligation of the governor: 
a. Uphold and implementing Pancasila, performing the Constitusional of the Republic of Indonesia coupled with defending and maintaining the unity of Indonesia;

b. Obey all provisions of the laws;

c. Develope democracy environment;

d. Maintain ethics and norms in implementing governmental task;

e. Performing the principal of good governance;

f. Conducting National Strategic Programs;

g. Establish cooperation with all departments in the regional government; and

h. Presenting report concerning all activities that are conducted by the regional government.

\section{Specific Faults}

Specific faults are stated in article 83 paragraph

(1) The Law Number 23 of 2014 are:

a. Performing criminal act which can be convicted minimum 5 years in prison;

b. Performing corruption;

c. Performing terrorism act;

d. Performing treason act;

e. Performing criminal act toward national security and/or

f. Performing other acts which can threat the unity of Indonesia.

\section{Not Performing National Strategic Program}

Not performing the national strategic program can be regarded as faults which can cause dismissal of the governor as referred in article 68 paragraph (1) The Law Number 23 of 2014. The national strategic program means program that is stipulated by Indonesian President which aims for national agenda and it is strategic as an effort to increase economic growth, spread development in all areas, maintain defense and security, coupled with to increase public wealth.

According to the classification of faults mentioned above The Law Number 23 of 2014 also distinguish mechanism of dismissal for the governor. In case of governor performing general faults, the dismisaal can be done through general procedure for instance proposing draft to Regional Representative Council as referred in article 79, 82 and 85 The Law Number 23 of 2014 concerning dismissal of governor trough the announcement procedure at the Regional Representative Council (DPRD) plenary session, rights to declere an opinion, and rights of investigation, rights of interpellation and investigation. In the case of governor performing specific faults, the dismissal can be done through the temporary dismissal by the President until judicial decisions has been annaouced by the court (inkracht van gewijsde) as referred to article 83 and 84 The Law Number 23 of 2014. In the case of governonr not performing national strategic program, the dismissal procedure can be done through administrative penalty by the President as referred to the Laws article 68 The Law Number 23 of 2014. The dismissal mechanism of governor can be seen on the chart below:

a. Dismissal of governor trough the announcement procedure at the DPRD plenary session

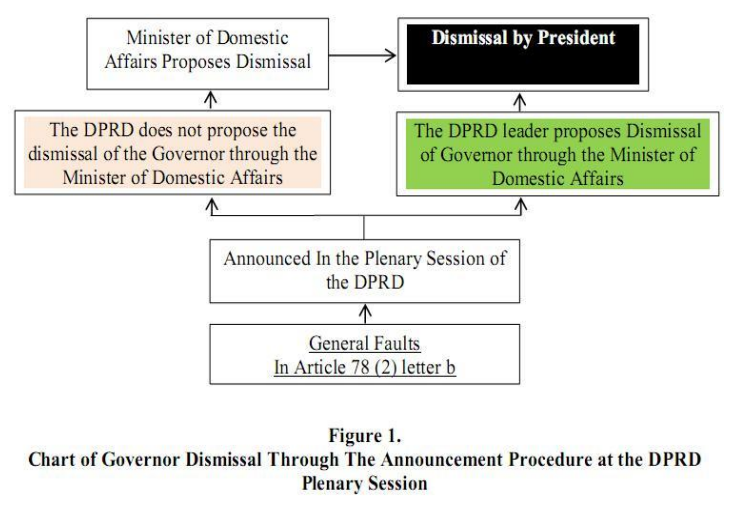


b. dismissal of governor trough the rights to declere an opinion

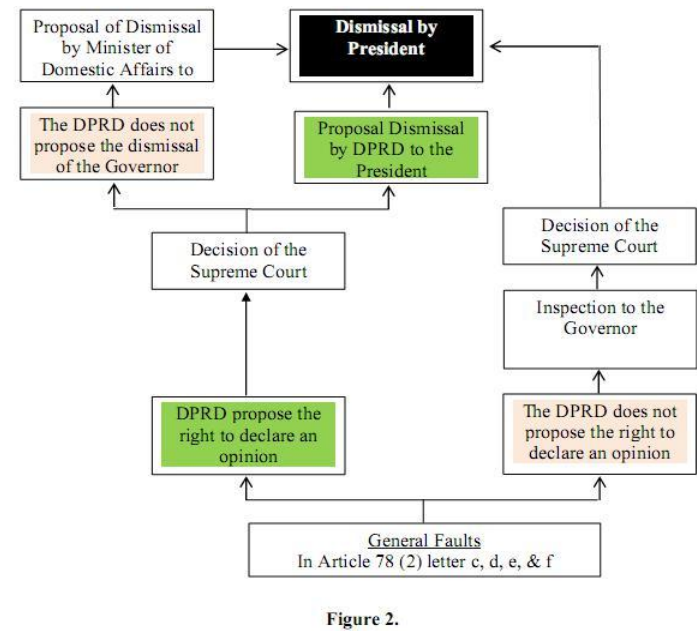

c. dismissal of governor trough the rights of investigation

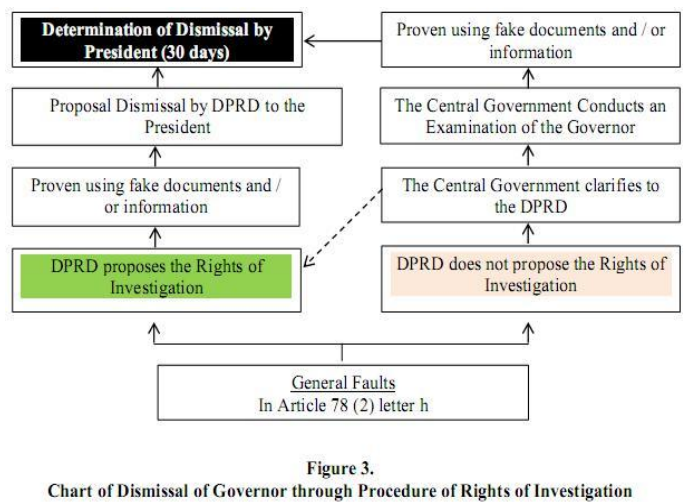

d. dismissal of governor trough the rights of interpellation and investigation

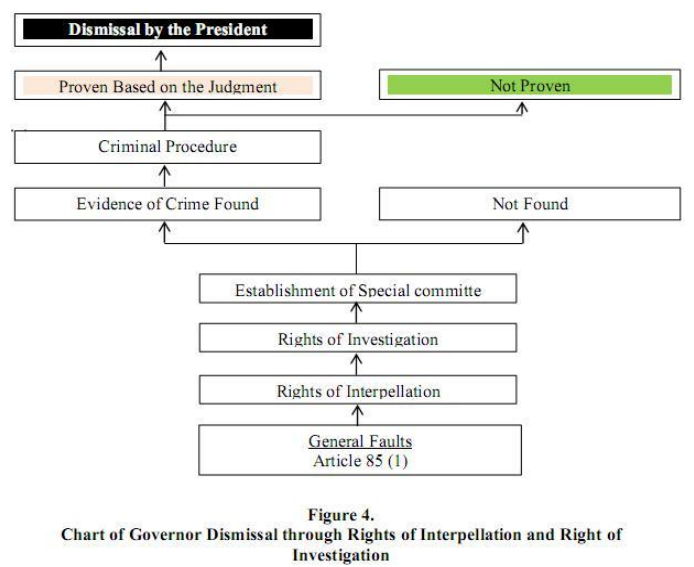

e. dismissal of governor trough the temporary dismissal by the President until judicial decisions has been annaouced by the court

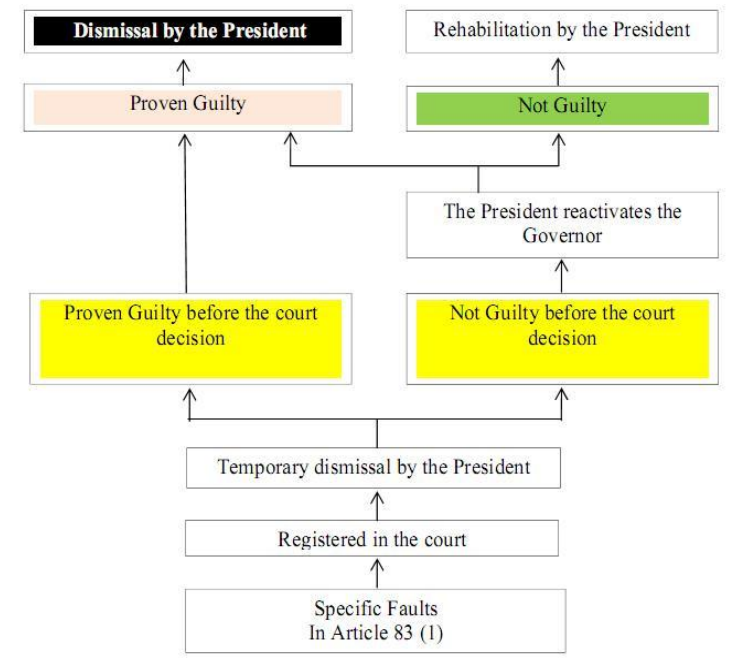

Figure 5.

The Governor's Dismissal Chart Through Special Mechanisms for Making Special Faults

f. dismissal of governor trough the administrative penalty by the President

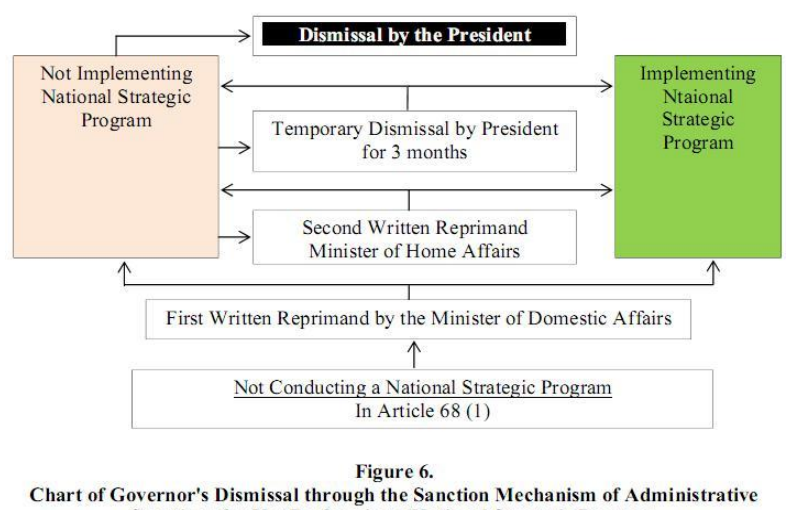
Sanctions for Not Performing a National Strategic Program

When the Regional Representatives Council and President do not propose dismissal concerning the faults that are performed by the governor, the President shall dismiss the governor if the court decision has been obtained (inkracht van gewijsde), as refrred in to article 87 paragraph (1) The Law Number 23 of 2014 
"If the governor stops as referred to in Article 78 or dismissed by a court decision which has obtained legal force, the governor shall continue to fill in accordance with the provisions of legislation regarding the election of regional head."

The dismissal of governor as referred in The Law Number 23 of 2014 basically appropriate with geen bevoegdheid zonder verantwoordelijkheid (no authority without responsibility) 6 , because all forms of faults from the use of authority liable in the form of dismissal from his or her position as the Governor. The dismissal of the Governor shall be levied in accordance with the classification of the faults. The mechanism of dismissal of the Governor is in accordance with the classification of the form of faults set out in The Law Number 23 of 2014 is a form of applying the principle of justice in the dismissal of the Governor.

\section{DISMISSAL OF THE GOVERNOR OF DKI JAKARTA ON CHARGE OF BLASPHEMY CRIME}

Basuki Tjahaja Purnama, who was the Governor of DKI Jakarta, was charged with criminal defamation in Article 156a letter a of the Criminal Code with the threat of imprisonment for 5 (five) years and Article 156 of the Criminal Code with a maximum imprisonment of 4 (four) years imprisonment. Basuki Tjahaja Purnama has been a defendant in the North Jakarta District Court on December $01,2016$.

Legal norms in Article 83 paragraph (1) and paragraph (2) The Law Number 23 of 2014 states that the Governor charged with a criminal offense punishable by a minimum imprisonment of 5 (five) years imprisonment by the President since the status of the defendant based on the court's case register. The question is whether the criminal act of blasphemy in Article 156a letter a of the Criminal Code with the threat of imprisonment for a maximum of 5 (five) years can be used as an excuse to temporarily dismiss Basuki Tjahaja Purnama as Governor of DKI Jakarta since the status of defendant in North Jakarta District Court?

The Indonesian Penal Code only recognizes the general minimum threats, maximum general and special maximum. The minimum threat is one day. The general maximum threat is 15 (fifteen) years and may become 20 (twenty) years if the offense is punishable by capital punishment or life in prison or in the event of a criminal offense. For specific maximum threats are included in each of the offenses in the Criminal Code 7.

According to Andi Hamzah that the absence of a specific minimum threat in the Criminal Code and the law outside the Criminal Code is a form of weakness because judges have very wide freedom in imposing criminal penalties and result in different sentences against similar crimes. Therefore, in the law outside the Criminal Code has set a special minimum threat.

The law outside the Criminal Code formulates minimum threats with the phrase "the shortest" and formulates the maximum threat with the phrase "the longest"8. For example the formulation of minimum threats and maximum threats is in Article 12B paragraph (2) Law Number 20 Year 2001 regarding the Amendment of Law Number 31 Year 1999 concerning the Eradication of Corruption, namely "Criminal for the civil servant or state official as referred to in paragraph (1) shall be a life imprisonment or imprisonment of a minimum of 4 (four) years and a maximum of 20 (twenty) years, and a fine of at least $\mathrm{Rp} 200,000,000.00$ (two hundred million rupiah) and a maximum of $\mathrm{Rp}$ $1,000,000,000.00$ (one billion rupiah) ".

In accordance with the above punishment system, the formulation of prison imprisonment for a minimum of 5 (five) years as referred to in Article 83 paragraph (1) The Law Number 23 of 2014 is a special minimum threat category. It means that a maximum imprisonment of 5 (five) years imprisonment as referred to in Article 156a letter a of the Criminal Code is not a basis for temporary suspension of Jakarta 
Governor Basuki Tjahja Purnama, since the imprisonment of the prison term specified in 156a letter a of the Criminal Code is special maximum threats, not specific minimum threats.

Based on the above analysis, Jakarta Governor Basuki Tjahaja Purnama can not be temporarily dismissed by the President by reason of being a defendant in the North Jakarta District Court for being charged with blasphemy with a maximum imprisonment of 5 (five) years as referred to in Article 156a letter a of the Criminal Code. Nevertheless, the Governor of Jakarta Basuki Tjahaja Purnama may be dismissed by the President for different reasons, in the form of a reason for making a general faults as mentioned in Article 78 paragraph (2) letter $\mathrm{c}$ and $\mathrm{d}$ and Article 85 paragraph (1) The Law Number 23 of 2014.

A general faults that can be taken as the dismissal of the Governor of Jakarta Basuki Tjahaja Purnama is as mentioned in Article 78 paragraph (2) letter $\mathrm{c}$ and letter $\mathrm{d}$ The Law Number 23 of 2014, which are:

\section{Violate the oath / appointment of governor}

The provisions concerning the Governor's oath / pledge are stipulated in Article 61 paragraph (2) The Law Number 23 of 2014, namely:

By Allah / God, I swear / promise to fulfill my duty as the regional head as best and fair as possible, uphold the 1945 Constitution of the Republic of Indonesia, and carry out all its laws and regulations as well as devote to the people, nusa, and nation.

2. Not performing the obligation of the Governor is not obeying all the provisions of the laws and regulations as referred to in Article $67 \mathrm{~b}$ The Law Number 23 of 2014.

Article 61 paragraph (2) and Article 67 letter b The Law Number 23 of 2014 mentioned above shall bear the obligation for the Governor to comply with all legal norms contained in the laws and regulations, including the legal norms contained in Article 156a a and 156 of the Criminal Code. If there is a violation of the legal norms in Article 156a letter a and Article 156 of the Criminal Code, then the Governor of DKI Jakarta Basuki Tjahaja Purnama may be dismissed from his position in accordance with the general mechanism through the procedure of the rights to declare an opinion by the Regional Representatives Council as described in Figure 2 above.

In addition, Article 85 paragraph (1) The Law Number 23 of 2014 can also be used as a reason for the dismissal of Jakarta Governor Basuki Tjahaja Purnama for committing a general crime in the form of a criminal act, which is facing a widespread public confidence crisis due to allegations of committing a crime related to his duties, authorities and obligations. The alleged blasphemy by Basuki Tjahaja Purnama was carried out during his duty as Governor of DKI Jakarta in the thousand islands on September 27, 2016 and has caused a very widespread confidence crisis. Therefore, the reasons for dismissal under Article 85 paragraph (1) The Law Number 23 of 2014 can also be justified. Dismissal of Jakarta Governor Basuki Tjahaja Purnama on the grounds of Article 85 Paragraph (1) The Law Number 23 of 2014 is conducted in accordance with the general mechanism through the rights of interpellation procedure and rights of investigation as described in Figure 4 above.

The indictment of religious blasphemy by Basuki Tjahaja Purnama is directly done through the judicial process. Therefore, the dismissal of Jakarta Governor Basuki Tjahaja Purnama in accordance with the general mechanisms described in Figure 2 and Gamber 4 above can no longer be used by DPRD or by the Central Government, because it will result in 1 (one) criminal case being examined and tried by 2 (two) judicial institutions simultaneously, namely the general court and the Supreme Court, this is certainly contrary to the principle of legal certainty. Although the general mechanisms in accordance with Figures 2 and 4 can no longer be used by the DPRD or by the Central Government, it does not mean that Basuki Tjahaja Purnama will be free from responsibility if based on the results of the court 
hearing has been found guilty of blasphemy and his verdict has obtained legal force permanent. According to Article 87 paragraph (1) The Law Number 23 of 2014 states that "If the governor resigns as intended in Article 78 or dismissed by a court decision which has obtained legal force, the governor shall continue to fill in accordance with the provisions of legislation regarding the election of regional head." Based on this provision, then if the blasphemy indictment by Basuki Tjahaja Purnama has been proven guilty based on a court decision that has obtained permanent legal force, therefore Basuki Tjahaja Purnama shall be dismissed from his position as Governor of DKI Jakarta by the President.

\section{CONCLUSION}

1. The Law Number 23 of 2014 has set out in detail the mechanism of dismissal of the Governor in accordance with the classification of faults. The classification of faults includes general faults, special faults, and fault by not performing a national strategic program. Therefore, any faults made by the Governor is not free from the responsibility of dismissal as Governor. Regulation of Governor's termination in The Law Number 23 of 2014 is in accordance with the principle of geen bevoegdheid zonder verantwoordelijkheid (no authority without responsibility).

2. The blasphemy crime charged on Basuki Thajaja Purnama with a maximum imprisonment of 5 (five) years in Article 156a letter a of the Criminal Code can not be a reason for temporary dismissal as the Governor of DKI Jakarta, due to the imprisonment of a minimum of 5 (five) years as referred to in Article 83 paragraph (1) The Law Number 23 of 2014 is a special minimum threat, while the imprisonment for a maximum of 5 (five) years in Article 156a letter a of the Criminal Code includes a special maximum threat. Nevertheless, Jakarta Governor Basuki Tjahaja Purnama may be dismissed for another reason, namely the reason for making a general faults in Article 78 paragraph (2) letter c and letter d and Article 85 paragraph (1) The Law Number 23 of 2014. The blasphemy crime case by Basuki Tjahaja Purnama is done through the judicial process, the DPRD and the Central Government can not use its authority to dismiss. The permanent replacement of Jakarta Capital City Governor Basuki Tjahja Purnama can only be made if based on the result of the examination in court has been proven guilty of blasphemy and his decision has obtained permanent legal force.

Based on two conclusions mentioned above, the present study recommends:

1. To make changes regarding the mechanism of temporary dismissal of the Governor in The Law Number 23 of 2014. The mechanism of temporary dismissal of the Governor by the President should be made against a Governor who commits a criminal offense punishable by imprisonment of 5 (five) years or more. The stipulation of such dismissal shall take place since the status of the defendant based on court registers, not on the basis of the criminal penalties charged in the indictment.

2. The permanent dismissal of a Governor who has been charged with blasphemy through a judicial process shall be conducted by the President if later found guilty on the basis of a court decision having obtained permanent legal force (inkracht van gewijsde). This is in accordance with Article 87 paragraph (1) of The Law Number 23 of 2014.

\section{REFERENCES}

[1] Arief, Barda Nawawi, Bunga Rampai Kebijakan Hukum Pidana, Bandung: Citra Aditya Bakti, 2002. 
[2] Hadjon, Philipus M. dan Tatiek Sri Djatmiati, Argumentasi Hukum, Cetakan Keempat, Yogyakarta: Gadjah Mada University, 2009.

[3] Hamzah, Andi, Sistem Pidana dan Pemidanaan di Indonesia, Jakarta: Pradnya Paramita., 1993.

[4] Manan, Bagir, Pertumbuhan dan Perkembangan Konstitusi Suatau Negara, Bandung: Mandar Maju, 1995.

[5] Nasution, Adnan Buyung, Aspirasi Pemerintahan Konstitusional di Indonesia, Studi Sosio-Legal atas Kunstituante 19561959, Jakarta: Pustaka Utama Grafiti, 1995.

[6] Vagts, Detlev, and Anne-Marie Burley, "Constitutionalism, Democracy, And Foreign Affairs", American Journal of International Law, Vol. 86, 1992.

Statute:

[7] The 1945 Constitution of The Republic of Indonesia

[8] Criminal Penal of The Republic of Indonesia

[9] The Law Number 12 of 2011 concerning Law Making

[10] The Law Number 23 of 2014 concerning Local Government

[11] The Law Number 9 of 2015 of The Second Amendment of The Law Number 23 of 2014 concerning Local Government

Media Internet:

[12] https://www.edunews.id/news/politik/initranskip-lengkap-ucapan-ahok-di-

kepulauan-seribu/, diakses pada tanggal 11 Maret 2017

[13] http://sipp.pn jakartautara.go.id/detil_perkara, diakses pada tanggal 4 Maret 2017 